\title{
Assessment of Traditional Knowledge Associated with Medicinal Plants in North Achfer District, Amhara Region, North Ethiopia
}

\author{
Tensay Ayalw*, Edeget Merawi \\ Ethiopian Biodiversity Institute, Bahir Dar Biodiversity Center, Bahir Dar, Ethiopia
}

Email address:

tensaye2006@gmail.com (T. Ayalw)

${ }^{*}$ Corresponding author

\section{To cite this article:}

Tensay Ayalw, Edeget Merawi. Assessment of Traditional Knowledge Associated with Medicinal Plants in North Achfer District, Amhara Region, North Ethiopia. Journal of Diseases and Medicinal Plants. Vol. 7, No. 2, 2021, pp. 35-43. doi: 10.11648/j.jdmp.20210702.12

Received: February 16, 2021; Accepted: June 17, 2021; Published: June 25, 2021

\begin{abstract}
The objective of the study was to document traditional knowledge on medicinal plants in north Achefer district. This study was conducted using semi-structured interviews using purposeful and random sampling methods. The collected data was analyzed using IBM SPSS statics 21software. A total of 65 informants 59 male and 6 female were interviewed from 5 kebele of north Achefer district. Among 65 informants only $12(18.5 \%)$ individuals are traditional healers and the rest 53 $(81.5 \%)$ persons were not traditional healers. A total of 74 medicinal plants were recorded for treating human and animal ailments through oral, dermal and nasal routs. From the collected medicinal plant species, $98 \%$ / of them were identified and the rest $2 \%$ / medicinal plant species were listed by their local name. Among 39 plant families the most frequently used plant species reported were Solanaceae $5(7.4 \%)$ and Euphorbiaceae 5 (7.4\%), Fabaceae $4(5.9 \%)$ and the least Lamiaceae $3(4.4 \%)$. In the study area medicinal plants affect by different factors, the main factors were human activity $(69.2 \%)$ by cutting; agricultural explanation, cultivating introduced species and natural factors (20\%) drought, erosion, hail and the rest (10.8\%) of respondents were reported that factors affected medicinal plants in the area. North Achefer woreda is rich in indigenous knowledge associated with medicinal plant but the distribution and diversity of medicinal plants have been declined at alarming rate. So attention should given and use best conservation methods to protect species from loss.
\end{abstract}

Keywords: Medicinal Plant, Traditional Knowledge, Threats

\section{Introduction}

Ethiopia is a land of great topographical diversity of high mountains, river valleys and rolling plains which are responsible for tropical, sub-tropical and temperate climatic conditions. The evolution and diversity of health problems and their causative agents is favored by the extreme physical and climatic conditions of the country [2]. Ethiopia is the fifth major country in tropical Africa in terms of the diversity of flora [3]. Ethiopia has attempted to come up with remedies or practices that restore good health in response to various health problems [2].

It was estimated that the Ethiopian flora contains about 6, 500 to 7000 species of higher plants [3]. Almost all plant species in the Ethiopian flora are used medicinally sometime in different area [16]. In Ethiopia, there is a long history of using medicinal plants to treat a variety of ailments [21]. $80 \%$ of the people use medicinal plants and plant remedies selected over centuries $[11,18]$. The vast majority of the rural populations, therefore, still depend on traditional medicine and its practitioners. Due to incomplete coverage of modern medical system, shortage of pharmaceuticals and unaffordable prices of modern drugs, the majority of peoples in the country still depend on traditional medicine [6].

Plants have played crucial role as a source of traditional medicine in Ethiopia from the time immemorial to combat different ailments and disease [10]. Plants have been an essential source of preventive and curative medicinal preparations for human beings. Different forms of remedy preparations and applications to treat live stock diseases are used. Due to accessibility, acceptability and biomedical benefits there is a large magnitude of use and interest of 
medicinal plants in Ethiopia. The plant materials include seeds, berries, roots, leaves, bark or flowers are used for medicinal value [13].

Traditional knowledge is information of indigenous or local communities as secret oral traditions that have been passed down over generations, but it may also be documented in publicly available written or even electronic media. Traditional knowledge is generally includes the intellectual and intangible cultural heritage, practices and knowledge systems of traditional communities, including indigenous and local communities. The terms traditional knowledge is frequently used as categories of culturally specific knowledge, since knowledge on a subject or held by a particular group of society. Documenting traditional medical knowledge is important to facilitate the discovery of new sources of drugs and promote sustainable use of natural resources [17]. On the other hand, traditional practices have their own contributions to the modern ones and hence they have to be maintained through detailed studies and documentation [14].

Traditional people around the world possess unique knowledge of plant resources on which they depend for food, medicine and general utility including tremendous botanical expertise [9]. Although various animal and mineral products contribute to human welfare, the plant kingdom is most essential to human wellbeing especially in supplying his basic needs. The relationship between humans and plants is as old as human existence on earth [13].

As reported by Ensermu Kelbessa et al, Ethiopia's traditional medicine, as elsewhere in Africa, is faced with problems of continuity and sustainability [3]. As medicinal plants are part of the total plant of the different ecosystems of the earth, they are affected by anthropogenic and natural forces. And majority of medicinal plants utilized in Ethiopia are part of forest and rangeland. Therefore, most off the threats to the forest and rangeland plants are also threats to medicinal plants. Nowadays herbal practitioners have to walk greater distance for collection of herbal medicine that once grew in the vicinity of their homes [13]. Deforestation, soil erosion, overgrazing and drought are the major factors that affect different medicinal plants [7, 20]. Unwillingness of young generations to gain the traditional knowledge, giving high credit to modern education is factors beside other natural conditions and anthropogenic activities [7]. Most people in Ethiopia especially young generation ignored the traditional knowledge. Documentation of traditional knowledge and conservation of plants should necessary. The general objective of the study is to document traditional knowledge of medicinal plant in north Achefer district.

\section{Materials and Methods}

\subsection{Description of Study Area}

The study was conducted from September 1-29/10/2018 G. $\mathrm{C}$ in north Achefere district. North Achefer district is one of the thirteen woredas found in West Gojjam Administrative Zone, is located $60 \mathrm{~km}$ south-west of Bahir Dar town, the capital of Amhara Region. It borders North Achefer to the north, Awi zone to the south and west and Mecha woreda to the east. It is sub-divided into 18 rural and 2 urban kebele administrations.
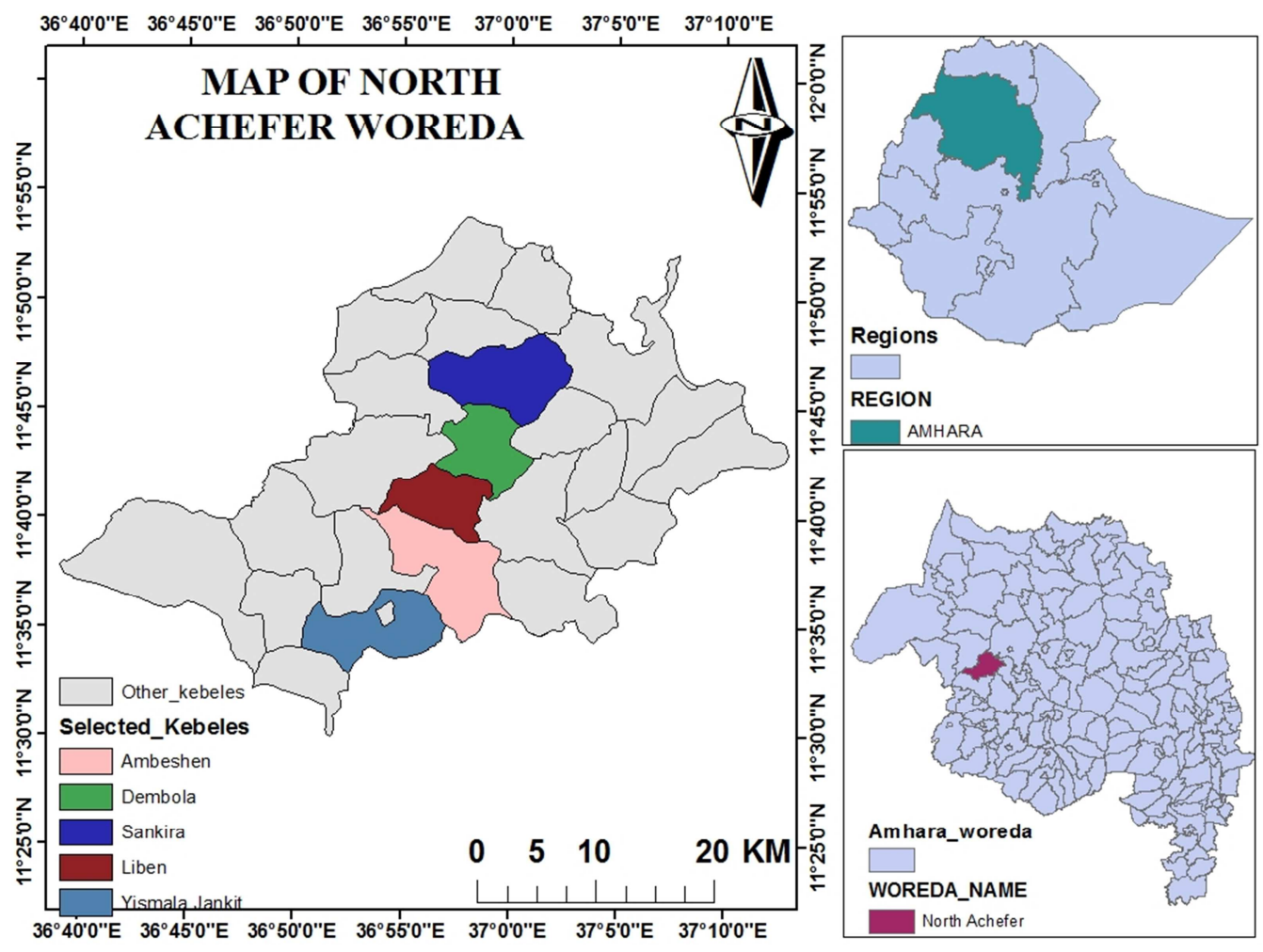

Figure 1. Map of the study area. 


\subsection{Materials}

Materials used during the study were Digital camera, GPS, laptop computer, pressing materials, plastic bag and note book.

\subsection{Methodology}

\subsubsection{Study Population}

The population of the study was targeted to those local people having traditional knowledge around the selected 5 kebeles of North Achefer woreda of Amhara region. The respondents were selected randomly considering different age group and gender.

\subsubsection{Data Collection}

Traditional knowledge of medicinal plant data was collected from September 1-29/10/2018 G. C methods following [9, 1]. Data was collected by applying semi structured questionnaire. Six kebeles were selected from the study area using purposive sampling techniques based on the distribution of different plant species and traditional medicinal value to treat different diseases. A total of 65 individual were interviewed using semi-structured interviews. Among the total respondents 12 of them the respondents were traditional healers which are selected by using purposive sampling technique to gather the relevant data. Openended and be close-ended questionnaires were applied during data collection to get valuable information. All of the questioners were asked by their local language (Amharic). The information collected included local/ vernacular name of the traditional medicinal plant, diseases treated, parts used, condition of plant used, method of preparation, route of administration, ingredients added, storage, side effects, other uses of the plant and existing threats and area of grown. Specimens of medicinal plants were collected and identified using the published volumes of the Flora of Ethiopia and Eritrea.

\subsubsection{Sampling Size and Sampling Techniques}

North Achefer district is one of the thirteen districts found in West Gojjam Administrative Zone. The woreda is selected based on purposive sampling method. Study was conducted from different kebeles based on traditional knowledge of the community.

\subsubsection{Data Analysis}

The collected data was coded, entered into excel sheet and analyzed using IBM SPSS Statistics version 21 software. The data were presented and summarized using descriptive statistics. The result was expressed in table, graph words and percent.

\section{Results}

\subsection{House Hold Characteristics}

\subsubsection{Educational Level of Respondents}

The study was undertaken from 65 informants 59 male and 6 female from 5 kebele of north Achefer district. Among the total respondent $56(86.15 \%)$ of them were illiterate whereas, the other group has primary education like writing and reading 9 (13.84\%). Mostly the traditional knowledge of herbal medicine was held by illiterate group of the respondent.

Table 1. Educational level of respondents.

\begin{tabular}{lll}
\hline School level & frequency & percent \\
\hline Illiterate & 56 & 86 \\
Primary & 6 & 9.2 \\
Secondary & 3 & 4.8 \\
Total & 65 & 100 \\
\hline
\end{tabular}

\subsubsection{Job Category of Respondents}

The respondent of the study area were farmers and their livelihood relies on agriculture $(72 \%)$, petty trading (3\%), animal fattening $(5 \%)$, and forest product selling mostly Eucalyptus spp. (10\%).

\subsubsection{Traditional Healers}

Among 65 informants only $12(18.5 \%)$ individuals are traditional healers and the rest $53(81.5 \%)$ persons of the informants are not traditional healers (table 2). It showed that majority of the community are not much familiar with traditional medicinal knowledge. They simply use by asking those traditional healers and receiving the prepared amount of medicine for the disease happen at a time.

Table 2. The traditional healers and nontraditional healers proportion in the study area.

\begin{tabular}{clll}
\hline Traditional healer & Frequency & Percent & Valid Percent \\
\hline Yes & 12 & 18.5 & 18.5 \\
No & 53 & 81.5 & 81.5 \\
Total & 65 & 100.0 & 100.0 \\
\hline
\end{tabular}

\subsection{Diversity of Medicinal Plant}

A total of 75 plant species collected during the study. Among collected species 68 of them belonging to 39 families were identified. From the identified families the frequently used medicinal plant species were reported to Solanaceae represented by $5(7.4 \%)$ and Euphorbiaceae $5(7.4 \%)$ and the rest family showed in table 3 .

Table 3. Medicinal plant diversity by their family.

\begin{tabular}{llll}
\hline No & Family & Frequency \\
\hline 1 & Acantaceae & 2 & \\
2 & Alliaceae & 1 & 2.9 \\
\hline
\end{tabular}




\begin{tabular}{|c|c|c|c|}
\hline No & Family & Frequency & $\%$ \\
\hline 3 & Aloaceae & 2 & 2.9 \\
\hline 4 & Amaranthaceae & 1 & 1.5 \\
\hline 5 & Apiaceae & 1 & 1.5 \\
\hline 6 & Apocynaceae & 2 & 2.9 \\
\hline 7 & Asclepiadaceae & 1 & 1.5 \\
\hline 8 & Asparagaceae & 1 & 1.5 \\
\hline 9 & Asteraceae & 2 & 2.9 \\
\hline 10 & Bignoniacea & 1 & 1.5 \\
\hline 11 & Boraginaceae & 1 & 1.5 \\
\hline 12 & Cactaceae & 2 & 2.9 \\
\hline 13 & Capparidaceae & 1 & 1.5 \\
\hline 14 & Crassulaceae & 1 & 1.5 \\
\hline 15 & Cucurbitaceae & 3 & 4.4 \\
\hline 16 & Ebenaceae & 1 & 1.5 \\
\hline 17 & Euphorbiaceae & 5 & 7.4 \\
\hline 18 & Fabaceae & 4 & 5.9 \\
\hline 19 & Lamiaceae & 3 & 4.4 \\
\hline 20 & Malvaceae & 2 & 2.9 \\
\hline 21 & Menispermaceae & 2 & 2.9 \\
\hline 22 & Moraceae & 2 & 2.9 \\
\hline 23 & Myrtaceae & 2 & 2.9 \\
\hline 24 & Oleaceae & 1 & 1.5 \\
\hline 25 & Phytolaccaceae & 2 & 2.9 \\
\hline 26 & Plantaginaceae & 1 & 1.5 \\
\hline 27 & Podocarpaceae & 1 & 1.5 \\
\hline 28 & Polygonaceae & 2 & 2.9 \\
\hline 29 & Ranunculaceae & 2 & 2.9 \\
\hline 30 & Rhamnaceae & 1 & 1.5 \\
\hline 31 & Rutaceae & 2 & 2.9 \\
\hline 32 & Sapindaceae & 1 & 1.5 \\
\hline 33 & Scrophulariaceae & 1 & 1.5 \\
\hline 34 & Simaroubaceae & 1 & 1.5 \\
\hline 35 & Solanaceae & 5 & 7.4 \\
\hline 36 & Strychnaceae & 1 & 1.5 \\
\hline 37 & Thymelaeaceae & 2 & 2.9 \\
\hline 38 & Tiliaceae & 1 & 1.5 \\
\hline 39 & Vitaceae & 1 & 1.5 \\
\hline Total & & 68 & 100 \\
\hline
\end{tabular}

\subsection{Medicinal Value of Plants}

Most plants are used for threat human and animal disease. In addition to cure ailment most plant products are used directly for food as spice, vegetable and fruit. Consumption of these herbs and spices as part of a normal diet is not likely to cause adverse herb-drug interactions because they are consumed in relatively small quantities. However, when these herbs and spices are utilized for medicinal purposes there may be an increased likelihood of adverse interactions with conventional medicines. Plant parts used is varying based on the plant and disease treat leave, root and fruit are the common plant parts applied to treat disease. A total of 76 medicinal plants were recorded to use as medicinal plant by informant through oral, dermal and nasal routs. The most commonly used plant parts for preparation in the study area were root, bark, leave and fruits. Table 1 showed the local name of the plant, scientific name parts used and threats of disease.

Table 4. Plant species type and parts used.

\begin{tabular}{|c|c|c|c|c|c|}
\hline \multirow[t]{2}{*}{ No. } & Local name & Scientific name & Family & Parts used & Disease treated \\
\hline & Abathareg & Clematis longicauda & Ranunculaceae & Root & To treat hyena bite \\
\hline & Aderqet & & & Leaves & To treat wound \\
\hline & Awetegn & Physalis peruviana & Solanaceae & Leaf & For fungal disease, animal bit \\
\hline & Dokima & Syzygium guineense & Myrtaceae & Root & to treat donkey pain \\
\hline & Enkoy & & & Bark & to stop tonsil pain \\
\hline & Gemero & Capparis tomentosa & Capparidaceae & Root & Evil eye \\
\hline & Gorgegit & Sida schimperiana & Malvaceae & Leaf & To treat flesh wound and to stop bleeding \\
\hline & Hargeablalit & Tragia spp & Euphorbiaceae & Leaf & To treat injured \\
\hline & Merzenchet & & & Root, stem & snake bite, swelling, donkey hemorrhoid \\
\hline & Shimgegit & Triumfetta pilosa & Tiliaceae & Root & evil eye \\
\hline & Tazema & & & Liquid & Botch \\
\hline & Temnahi/wenahe & Flueggea virosa & Euphorbiaceae & Root & evil eye, \\
\hline & 9Yeahiya zeqaqebae & & & Leaf & To stop cow abortion \\
\hline & Yebabhareg/alenga & Indigofera spicata & Fabaceae & Bark & Rabies \\
\hline
\end{tabular}




\begin{tabular}{|c|c|c|c|c|c|}
\hline No. & Local name & Scientific name & Family & Parts used & Disease treated \\
\hline & Yeqebrotelba & Gnidia glauca & Thymelaeaceae & Root & evil eye \\
\hline & Ymerzenchet & Acokanthera scimperi & Apocynaceae & Stem & For snake bite, donkey hemorrhoid \\
\hline & Ywusalomi & & & Root & For rabies, anthraxes \\
\hline & Zureshi & & & Leaf & Fungal disease \\
\hline & Kuseshela & Acantthus spp. & Acantaceae & Root & evil eye, Scorpion bit, animals Pain \\
\hline & Semiza & Justicia schimperiana & Acanthaceae & Leaf & to treat abdominal pain§ To remove placenta \\
\hline & Nechshnkurt & Allium сера & Alliaceae & Fruit & evil eye, abdominal pain \\
\hline & Ret & Aloe spp. & Aloaceae & Leaves & Animals pain \\
\hline & Ret & Aloe spp. & Aloaceae & & to treat fungal disease \\
\hline & Telenge & Achyranthes aspera & Amaranthaceae & Root & eye pain, fever \\
\hline & Dog & Ferula communis & Apiaceae & Root & to facilitate cows birth \\
\hline & Agam & Carissa spirarum & Apocynaceae & Root & evil eye \\
\hline & Tefrina & Tacazzea apiculata & Asclepiadaceae & Root & evil eye \\
\hline & Ysetqest & Asparagus africanus & Asparagaceae & Root & To treat toothache and evil eye, \\
\hline & Grawa & Vernonia amygdalina & Asteraceae & Leaves & animals pain/swallow \\
\hline & Qebercho & Echinops kebericho & Asteraceae & Root & To treat livestock bone Dislocation and animals cough \\
\hline & Zana & $\begin{array}{l}\text { Stereospermum } \\
\text { kunthianum }\end{array}$ & Bignoniacea & Bark & evil eye \\
\hline & Wanza & Cordia africana & Boraginaceae & Root/leaves & animals skin itch Diarrhea, fever \\
\hline & Kulkual & Opuntia spp. & Cactaceae & Root & Rabies \\
\hline & Ymiderqulqual & Opuntia spp. & Cactaceae & Root & Evil eye \\
\hline & Anedahula & Kalanchoe petitana & Crassulaceae & Steam & $\begin{array}{l}\text { To treat flesh woundः livestock swellingฐ remove placenta } \\
\text { and fever }\end{array}$ \\
\hline & Aregrsa & Zehneria scabra & Cucurbitaceae & Leaf, steam & Fever, ox sore, Abdominal pain eye pain \\
\hline & Qurahareg & Momordica foetida & Cucurbitaceae & Hole parts & To treat ox sore \\
\hline & Yemderembuay & Cucumis ficifolius & Cucurbitaceae & Root & To treat eczema \\
\hline & Dedho & Euclea racemosa & Ebenaceae & Root & $\begin{array}{l}\text { To stop hating of cows there calf when it birth, Abdominal } \\
\text { pain }\end{array}$ \\
\hline & Abelalit & Tragia spp. & Euphorbiaceae & Root & To treat animal bite \\
\hline & Gulo/qachima & Ricinus communis & Euphorbiaceae & Root & To treat anthraxes \\
\hline & Mesana & Croton macrostachyus & Euphorbiaceae & Bark & $\begin{array}{l}\text { Abdominal pain, to stop cows calves ignorance to protect } \\
\text { animals bite, evil eye }\end{array}$ \\
\hline & Beshbeshi & Lannia fructosa & Fabaceae & Leaf & To protect when a women got birth \\
\hline & Gerar & Acacia spp. & Fabaceae & Root & evil eye, \\
\hline & Zegeta & Calpurnia aurea & Fabaceae & Root & To treat snake bite \\
\hline & Tosegn & Thymus schimperi & Lamiaceae & Leaf & Fever, common cold \\
\hline & Tunjjt & Otostegia integrifolia & Lamiaceae & whole parts & common cold \\
\hline & Zeqaqbae & Ocimum americanum & Lamiaceae & Whole parts & Common cold \\
\hline & Chiferg & Sida debriana & Malvaceae & Root & Evil eye \\
\hline & Kibqetel & Stephania abyssinica & Menispermaceae & Root & To treat anthraxes \\
\hline & Yahiya joro & Stephania abyssinica & Menispermaceae & Root & evil eye \\
\hline & Bamba & Ficus sycomorus & Moraceae & Root & to treat uvula/ Tonsillitis, \\
\hline & Worqbemeda & Dorstenia barnimiana & Moraceae & Root & To treat flesh wound \\
\hline & Nechbahirzaf & Eucalyptus globulus & Myrtaceae & Leaf & to protect ants bite \\
\hline & Temebele & Jasminum grandiflorum & Oleaceae & Root & animals eye pain, ring worm \\
\hline & Enedod & Phytolaca dodecandra & Phytolaccaceae & & To treat anthraxes, rabbis \\
\hline & Mekanendod & Phytolaca spp. & Phytolaccaceae & Root & to treat rabbis, to remove animal skin lice \\
\hline & Gorteb & Plantago lanceolata & Plantaginaceae & Leaf & To treat injured \\
\hline & Zegeba & Podocarpus falcatus & Podocarpaceae & Root, leaf & to protect animals bite \\
\hline & Embacho & Rumex nervosus & Polygonaceae & Leaves & To treat animal wound, to stop bleeding and injured \\
\hline & Meqemqo & Rumex abyssinicus & Polygonaceae & Leaf & To treat fungal disease \\
\hline & Azoharg & Clematis simensis & Ranunculaceae & Leaf & To treat abdominal pain, cough \\
\hline & Esataberd & Helinus mystacinus & Rhamnaceae & Root & to stop fire pain \\
\hline & Lomi & Citrus aurantiifolia & Rutaceae & Epiphytes & Erestoblastosis/shotelay \\
\hline & Tenadam & Ruta chalepensis & Rutaceae & Leaf & To treat common cold and evil eye, \\
\hline & Keteketa & Dodonaea angustifolia & Sapindaceae & Leaves & For fracture/ any broken part of body, \\
\hline & Dabaqeded & Verbascum sinaiticum & Scrophulariaceae & Root & cough and Abdominal pain to protect blooding during birth \\
\hline & Yedegaabalo & Brucea antidysentrica & Simaroubaceae & Root & Abdominal pain \\
\hline & Astenager & Datura stramonium & Solanaceae & Fruit/leaves & To prepare abisho, to treat itching \\
\hline & Embuy & Solanum campylacanthum & Solanaceae & Root & evil eye, \\
\hline & Gezewa & Withania somnifera & Solanaceae & Leaf & To treat hepatitis stop kids fever \\
\hline & Zerchiembuay & Solanum anguivi & Solanaceae & Root, fruit & To treat syphilis, fungal disease \\
\hline & Doqema & Strychnos spinosa & Strychnaceae & Epiphytes & Erestoblastosis/ Shotelay \\
\hline & Yzengerotelba & Gnidia glauca & Thymelaeaceae & Root & To protect dogs from rabies \\
\hline & Aserkush & Cyphostemma adenocaule & Vitaceae & Root & evil eye \\
\hline
\end{tabular}




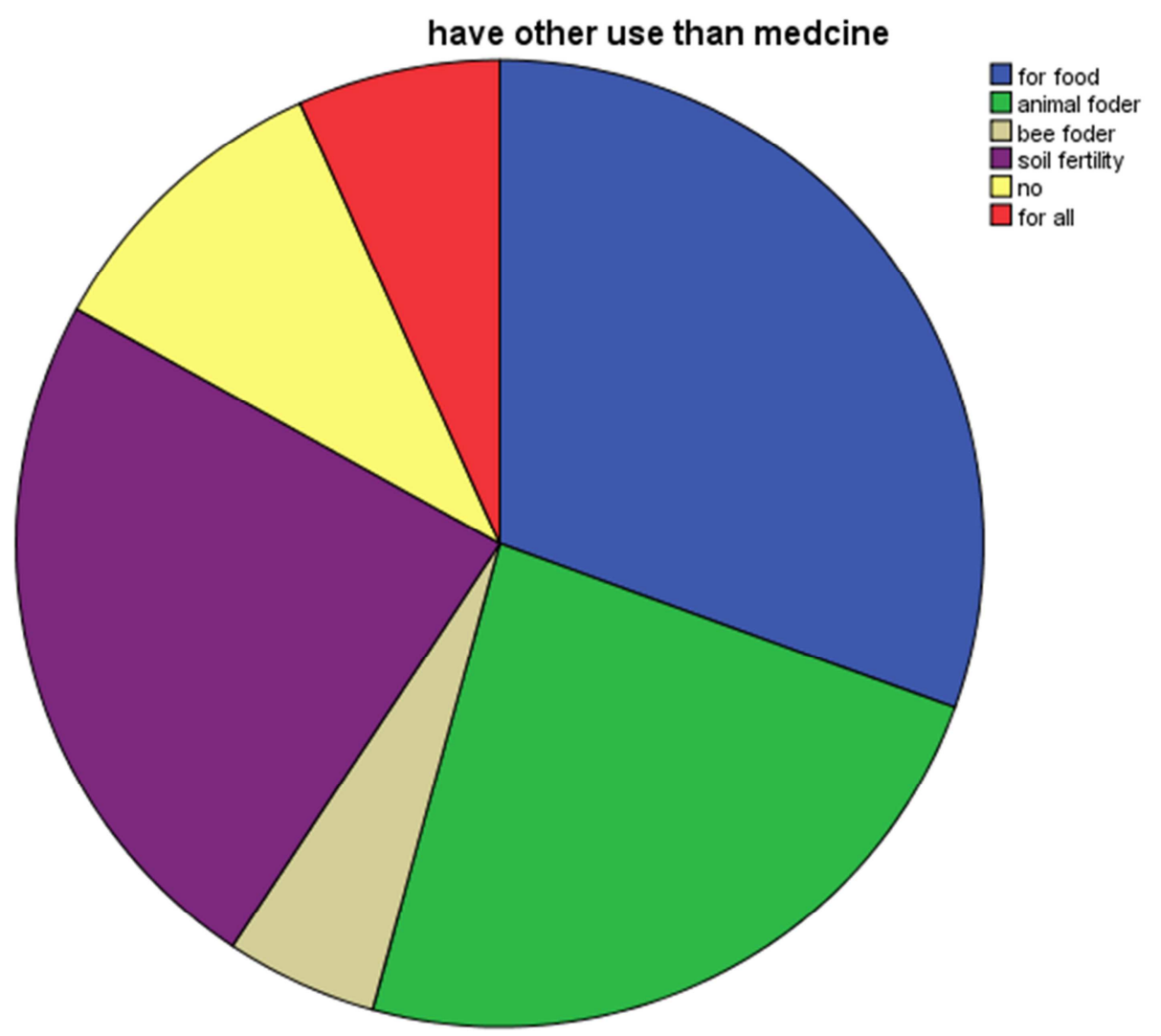

Figure 2. Use of plant in addition to medicine.

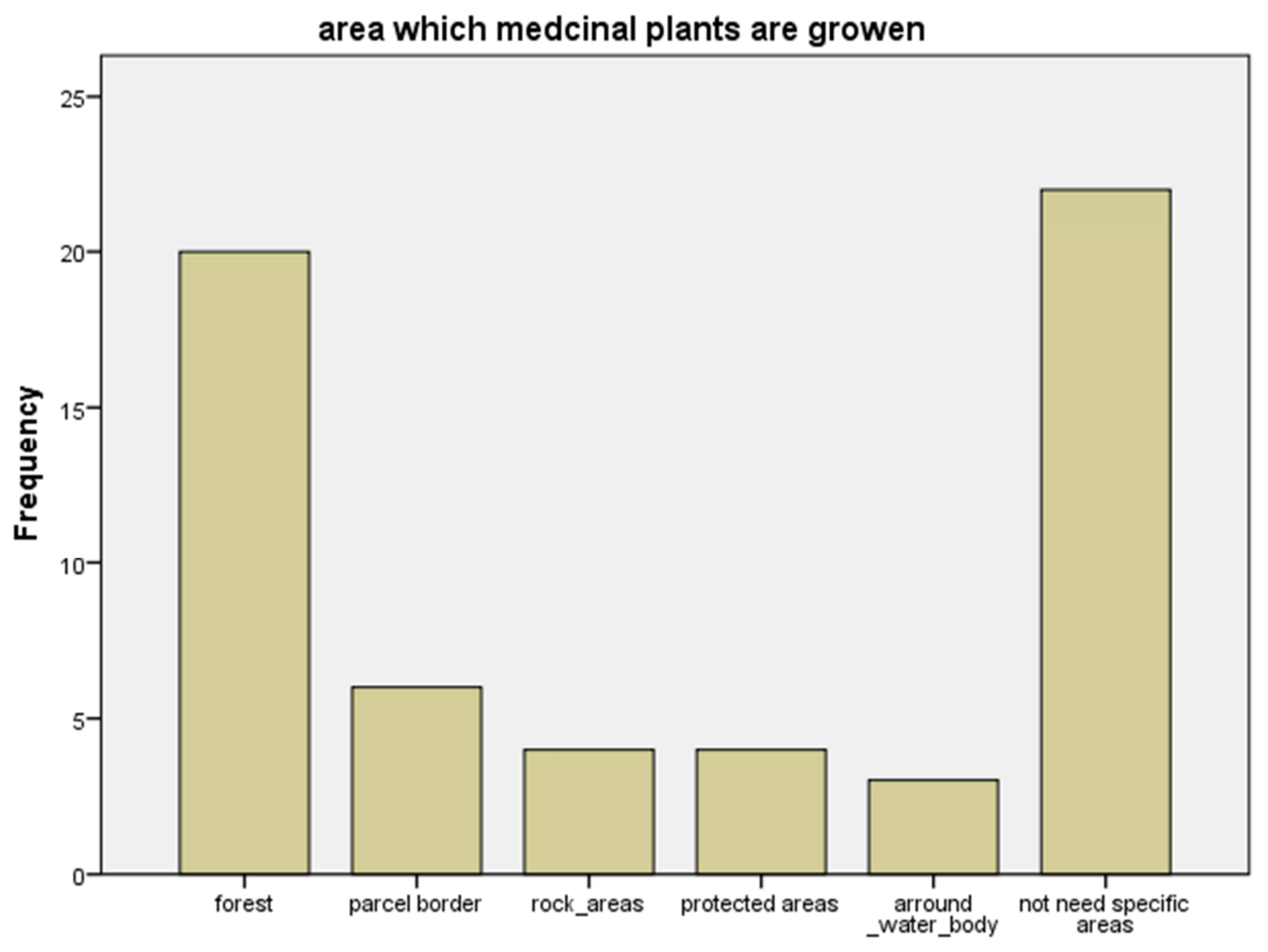

area which medcinal plants are growen

Figure 3. Growing area of medicinal plants. 


\subsection{Other Use of Medicinal Plants}

Medicinal plants used for community in deferent way in addition to cure human and animal malady. During the study respondent stated additional use of medicinal plants for food $(27.7 \%)$, fodder $(21.5 \%)$, bee fodder $(4.6 \%)$, soil fertility $(21.5 \%)$, for all $(6.2 \%)$ and the rest $(9.2 \%)$ respondent described medicinal plants used only for medicinal value.

\subsection{Medcinal Plant Growing Area}

Results from informant showed that medicinal plants can grow in the forest, farmland border, rock, protectedland and wetlandareas. Large species of medicinal plants are growing on natural forest and list numbers of plant species are available wetland and free human intervention area. As respondat result showed majority of medcinal plant grow with out requiring special place $(33.8 \%)$ and forest areas (30.8\%) and lessmedcinal plant species can grow arowend wetland areas (4.6\%) (figure 3). Tradational medicinal plant userscan collect plants from forest, homegarden, relatives or from markates.

\subsection{Tradational Medcine Use Practice by the Society}

In the study area plants used for medcine are native and servived for long period of time. In terms of threating the diseas, peoples in the study area showed that majority of the community ofused more modern medicen $(73.8 \%)$ than tradational medicen $(16.9 \%)$. The main reson stated by the respondents was peoples giving more truest for modern medcin trhan tradational medcin but it depends. $(9.2 \%)$ of respondat nither use tradational nor modern medcinal treatment. They prefer mor tradational medcine for ailment like buda (evil eye), yewefitu (heppatites) gunfan (comen cold) and mich.

\subsection{Factor Affecting Medicinal Plant Distribution}

Medicinal plants affect by different factors, the main factors affect in the study area was human activity $(69.2 \%)$ by cutting, agricultural explanation, cultivating introduced species and natural factors $(20 \%)$ drought, erosion, hail and the rest $(10.8 \%)$ of respondents were responded that factors affected medicinal plants in the area. Majority of respondent react over utilization (24.6\%), natural factor (3.1\%), giving less concern (23.1\%) lack of knowledge (6.2\%), deforestation (24.6\%) and agricultural explanation (9.2\%). The rest $9.2 \%$ of respondents have no idea why medicinal plants in their area are threaten (Table 4).

Table 5. Main cause for threats of medicinal plants in the area.

\begin{tabular}{llllll}
\hline threats of medicinal plants & Frequency & Percent & Valid Percent & Cumulative Percent \\
\hline \multirow{5}{*}{ Valid } & over utilization & 16 & 24.6 & 27.1 & 27.1 \\
& natural factor & 2 & 3.1 & 3.4 & 30.5 \\
& less concern & 15 & 23.1 & 25.4 & 55.9 \\
& lack of knowledge & 4 & 6.2 & 6.8 & 62.7 \\
& Deforestation & 16 & 24.6 & 27.1 & 89.8 \\
& expansion of agricultural practice & 6 & 9.2 & 10.2 & 100.0 \\
Missing & Total & 59 & 90.8 & 100.0 & \\
Total & System & 6 & 9.2 & & \\
\hline
\end{tabular}

\subsection{Solution for Medicinal Plant Threats}

Solutions stated by respondents were conservation (43.1\%), awareness creation (29.2\%) and forest protection (16.9\%).

\section{Discussion}

In the study area the respondent result showed that 11 $(16.9 \%)$ are use traditional medicine, 48 (73.8\%) use modern medicine and the rest $6(9.2 \%)$ of the respondent are neither use traditional nor modern medicine. This showed that the community in the area used more modern medicine than traditional medicine but research conducted by [15] showed that medicinal plants are the main, often only source of traditional medicine for the rural population in the health care systems of this population when compared to modern medicine. The shrubs and herbs were the most harvested for medicinal purpose than other life forms [19]. Similarly in this study result showed that herbs, shrubs and trees respectively used for medicinal value, but herbs are the most frequently used medicinal plants in the area.

Traditional healers were found to play an important role in the primary health care system of the rural people as they treat resource people who had little access and could not afford the cost of modern medication [15]. But in this study results showed that majority of the community prefer modern than using traditional medicine, the main reason stated was they trust more in modern than traditional healers. Also majority of the traditional healers were older than 46 years [16]. The same in this study majority of the traditional healers were older and young generations are not interested to have such traditional medicinal knowledge. They putted as reason to have less interest about medicinal knowledge is the people who have such knowledge have not used as source of income. Many traditional healers of the area held their indigenous knowledge in secret. The study conducted by [16] also reported, in Ethiopia it is very difficult to obtain their traditional medicinal information as they considered their indigenous knowledge as a professional secret, only to be passed orally to their older son, at their oldest age.

Medicinal plants affect by different factors, the main 
factors affect in the study area was human activity (69.2\%) by cutting, agricultural explanation, cultivating introduced species and natural factors $(20 \%)$ drought, erosion, hail and the rest $(10.8 \%)$ of respondents were responded that factors affected medicinal plants in the area. Majority of respondent react over utilization $(24.6 \%)$, natural factor $(3.1 \%)$, giving less concern (23.1\%), lack of knowledge $(6.2 \%)$, deforestation (24.6\%) and agricultural explanation (9.2\%). The rest $9.2 \%$ of respondents have no idea why medicinal plants in their area are threaten.

\section{Conclusions}

The study of traditional medicinal plants indicates that the study area contains different types of medicinal plants and the associated indigenous knowledge. Seventy six medicinal plants were recorded to treat human and animal ailments. The medicinal plant species were collected from the wild and homegardens. Among 74 collected species 72 species were identified by their scientific name and the rest 2 spp. were recorded by their local name. During the study informant results and observation showed that medicinal herbs are highly utilized than trees and shrubs and root part of the plant also take the first place in case of using for medicine. Mostly medicinal plants are applied in oral than other ways. The major threats to medicinal plants and the associated Knowledge in the study area were agricultural expansion, unsustainable utilization, giving less concern, drought and deforestation. Unwillingness of young generation to gain the knowledge, unavailability of the species, influence of modern education and less awareness are another factors. Traditional knowledge studies are required to introduce the existence of traditional practices as well as the rich plant species of the area and plant species of medicinal value that are used by traditional healers and the community to treat various health problems. The expansion of modern medical services and cultures cause for much of the traditional practices are getting less. Giving less respect for the knowledgeable and elders die without sharing their knowledge to the younger generation are the key problems for traditional knowledge transfer through generation. Therefore, awareness creation campaigns are timely needed to improve local community's knowledge on the importance and management of medicinal plants and awareness raising should be made among the healers so as to avoid erosion of the indigenous knowledge and to ensure its sustainable use. Most of the traditional healers in the study area were males and are married. This showed that they have family to support with the income realized from the sale and administration of the herbs.

\section{Acknowledgements}

We are grateful to thank people in north Achefer district particularly the traditional medical practitioners for sharing their valuable knowledge on medicinal plants of the area. We also thank Ethiopian institute of biodiversity Bahir Dar biodiversity center for financial support for the study.

\section{References}

[1] Cotton CM. Ethnobotany: Principles and Applications. John Wiley and Sons, Chichester, England. 1996, 347.

[2] Dawit Abebe, Asfaw Debela and Kelbessa Urga (2003). Medicinal and other useful plants of Ethiopia. EHNRI, Addis Ababa, Ethiopia.

[3] Ensermu Kelbessa, Sebsebe Demissew, Zerihun Woldu, Edwards S. Some threatened Endemic plants of Ethiopia. In: The status of some plants in parts of tropical Africa. (Edwards, S. and Zemede Asfaweds). NAPRECA, Botany 2000: East and Central Africa. 1992; 2: 35-55.

[4] Seifu T. Ethnobotanical and Ethnopharmaceutical studies on medicinal plants of Chifra District, Afar Region, North Eastern Ethiopia, (M. SC thesis unpublished). 2004.

[5] Fisseha Mesfin, Talemos Seta, and Abreham Assefa (2014) An Ethnobotanical Study of Medicinal Plants in Amaro Woreda, Ethiopia. Ethnobotany Research \& Applications 12: 341-354.

[6] Gidey Yirga and Samuel Zeraburk (2014) Ethnobotanical study of traditional medicinal plants in Gindeberet district, western Ethiopia.

[7] Kalayu Mesfin, Gebru Tekle, Teklemichael Tesfay (2013). Journal of Medicinal Plants Studies Ethnobotanical Study of Traditional Medicinal Plants Used by Indigenous People of Gemad District, Northern Ethiopia Journal of Medicinal Plants Studies1 (4) 32: 37.

[8] Kebede Deribe, Alemayehu Amberbir, Binyam Getachew, Yunis Mussema. A historical overview of traditional medicine practices and policy in Ethiopia

[9] Martin GJ. Ethnobotany: A Method Manual. Chapmanand Hall, London. 1995, 267-347.

[10] Pankhurst R. An introduction to medicinal history of Ethiopia. The Red Sea Press, Inc. New Jersey. 1990.

[11] Tesfaye Hailemariam, Sebsebe Demissew and Zemede Asfaw (2009). An ethnobotanical study of medicinal plants used by local people in the lowlands of Konta Special Woreda, southern nations, nationalities and peoples regional state, Ethiopia. Journal of Ethnobiology and Ethnomedicine, 5: 26 .

[12] Yayesh Limenih, Shemsu Umer and Messay Wolde-Mariam 2015. Ethnobotanical study on traditional medicinal plants in dega damot woreda, amhara region, north Ethiopia IJRPC, 5 (2), 258-273.

[13] Yeneayehu Fenetahun and Girma Eshetu 2017. A review on ethnobotanical studies of medicinal plants use by agropastoral communities in, Ethiopia. Journal of Medicinal Plants Studies; 5 (1): 33-44.

[14] Zewdie Kasa, 2009. An ethnobotanical study of medicinal plants and biodiversity of trees and shrubs in Jeldu Wereda, Western Shoa Zone (M. Sc. Thesis unpublished). Addis Ababa University.

[15] Zerabruk S. and Yirga G. 2012. Traditional knowledge of medicinal plants in Gindeberet district, Western Ethiopia. South African Journal of Botany 78: 165-169. 
[16] Jansen, 1981. Medicinal plants Spices, condiments and medicinal plants in Ethiopia, their taxonomy and agricultural significance. Spices and medicinal plants in Ethiopia. Wageningen

[17] Balick, M. J and Cox, P. A 1998. Etnobotanie: derol van planten in de meneselike culutur. Amesterdam, Natuure en techniek 229.

[18] Abebe, d. 1986. Traditional medicine in Ethiopia. The attempts being made for its effective and better utilization, SINET: Ethiop: J. Sci 9 (1): 61.

[19] Getnet Chekole 2017. Ethnobotanical study of medicinal plants used against human ailments in Gubalafto District,
Northern Ethiopia. Chekole Journal of Ethnobiology and Ethnomedicine 13: 55.

[20] Tesfaye S. Kaleab A and Tsige 2006. Ethnobotanical and ethnopharmaceutical studies on medicinal plant of Chifra district Afar region, northeast Ethiopia. Ethiopi. pharm. J., 24: 41-48.

[21] Kibebew F. 2001. The status and availability of oral and written knowledge on traditional healthcare in Ethiopia. In: Zewdu M, Demissie A, editors. Conservation and sustainable use of medicinal plants in Ethiopia. Proceedings of National Workshop on Biodiversity Conservation and Sustainable Use of Medicinal Plants in Ethiopia. 28 April to 01 May 1998. Addis Ababa: IBCR; 168-75. 